\title{
บusisersaly
}

\section{Ethical Review of Undergraduate Student Research Projects: A Proportionate, Transparent and Efficient Process?}

Hack, C. (2012). Ethical Review of Undergraduate Student Research Projects: A Proportionate, Transparent and Efficient Process? Bioscience Education, 19(8), 8. http://www.bioscience.heacademy.ac.uk/journal/vol19/beej19-8.aspx

Link to publication record in Ulster University Research Portal

Published in:

Bioscience Education

Publication Status:

Published (in print/issue): 01/01/2012

\section{Document Version}

Publisher's PDF, also known as Version of record

\section{General rights}

Copyright for the publications made accessible via Ulster University's Research Portal is retained by the author(s) and / or other copyright owners and it is a condition of accessing these publications that users recognise and abide by the legal requirements associated with these rights.

\section{Take down policy}

The Research Portal is Ulster University's institutional repository that provides access to Ulster's research outputs. Every effort has been made to ensure that content in the Research Portal does not infringe any person's rights, or applicable UK laws. If you discover content in the Research Portal that you believe breaches copyright or violates any law, please contact pure-support@ulster.ac.uk. 


\title{
Essay
}

\section{Ethical Review of Undergraduate Student Research Projects: A Proportionate, Transparent and Efficient Process?}

\author{
Catherine J Hack \\ University of Ulster
}

Date received: 06/02/2012

Date accepted: 21/05/2012

\begin{abstract}
Undergraduate research projects in the life sciences encompass a broad range of studies, some of which may require the participation of human subjects or other activities which may raise ethical concerns. As universities are accountable for all projects undertaken under their auspices they must ensure that these projects adhere to legal requirements, use acceptable research methods, represent an appropriate use of resources, and minimise risks to all research participants. Many student projects in UK universities are not subject to external review, and individual universities have established their own internal ethical review processes. This paper discusses the risks and benefits of student research projects, considers the range of ethical review processes performed in UK universities, and provides some suggestions for proportionate, transparent and efficient review of student projects.
\end{abstract}

Keywords: Ethical review, undergraduate research projects

\section{Introduction}

Evidence-based research is the primary driver through which science and medicine advances. All research represents a balance between risks and benefits; often the person taking the risk does not immediately (if ever) realise benefits, but these are gained by society as a whole. Biomedical research has always been in the vanguard of such conflicting interests, and as such has been the subject of regulation since the Nuremburg Code was developed in response to the horrific experiments carried out on inmates of Nazi concentration camps during the Second World War. The current system of review of biomedical research by Research Ethics Committee (REC), is based on the requirement for ethical review stipulated by the European Union: Clinical Trials Directive (20/2001/EC) and the Good Clinical Practice Directive (28/2005/ EC). It has evolved from a system of peer review (1973-1991), through peer regulation, to the establishment of national guidelines and regulation through Governance Arrangements for Research Ethics Committees (GAfREC) in 2001 (Hazelgrove, 2002)

However ethical issues are also raised in other areas of qualitative and quantitative research, for example in research that: involves human subjects in non-medical disciplines; non-human subjects; impacts on the environment; uses sensitive data; or, produces outcomes that may raise societal concerns. The requirement for ethical regulation for this type of research may appear ad hoc, and can be dependent on seemingly irrelevant factors such as the funding body or sponsor of the research, whether the research uses public resources, and the location of the research. Thus research into suicide ideation which would be subject to ethical review if carried out in a hospital or prison, may escape scrutiny if it were to take place in a community centre or via the internet. However if the research were undertaken as part of a research project for an educational qualification, then it should be expected that the sponsoring university will have procedures in place to safeguard both the researcher and the participants. As publicly funded institutions, UK universities are accountable to their immediate community of staff and students, and to the wider society that they serve. The general public is in support of medical research, and appreciate that medicines and other healthcare devices or services have to be tested. Their willingness to participate in research is based on a relationship of trust and transparency 
Table 1 Extract from Subject Benchmark Statements ${ }^{1}$

\begin{tabular}{|c|c|c|c|}
\hline Subject & Skills & $\begin{array}{l}\text { Research: A typical } \\
\text { should: }\end{array}$ & $\begin{array}{l}\text { Ethics: A typical } \\
\text { should: }\end{array}$ \\
\hline \multirow[t]{3}{*}{ Anthropology } & $\begin{array}{l}\text { The ability to plan, undertake } \\
\text { and present scholarly work that } \\
\text { demonstrates an understanding } \\
\text { of anthropological aims, methods } \\
\text { and theoretical considerations. }\end{array}$ & $\begin{array}{l}\text { Show a basic awareness } \\
\text { of the repertoire of } \\
\text { concepts, theories and key } \\
\text { research methods used in } \\
\text { anthropological analysis. }\end{array}$ & $\begin{array}{l}\text { Demonstrate an ability to } \\
\text { assess and analyse the } \\
\text { ethical implications of } \\
\text { anthropological research } \\
\text { and enquiry. }\end{array}$ \\
\hline & $\begin{array}{l}\text { The ability to analyse and } \\
\text { evaluate relevant qualitative } \\
\text { and quantitative data utilising } \\
\text { appropriate techniques. }\end{array}$ & & \\
\hline & $\begin{array}{l}\text { The ability to design and } \\
\text { implement a project involving data } \\
\text { collection on some aspect(s) of } \\
\text { human biological diversity, and } \\
\text { to display relevant investigative, } \\
\text { analytical and communication } \\
\text { skills }\end{array}$ & & \\
\hline $\begin{array}{l}\text { Biomedical } \\
\text { Science }\end{array}$ & $\begin{array}{l}\text { Have ability in a range of practical } \\
\text { techniques relevant to biomedical } \\
\text { science including data collection, } \\
\text { analysis and interpretation of those } \\
\text { data, and testing of hypotheses. }\end{array}$ & $\begin{array}{l}\text { Be able to plan, execute } \\
\text { and present an independent } \\
\text { piece of work (eg a } \\
\text { project) within a supported } \\
\text { framework in which qualities } \\
\text { such as time management, } \\
\text { problem solving and } \\
\text { independence are evident. }\end{array}$ & $\begin{array}{l}\text { Have some } \\
\text { understanding of } \\
\text { ethical issues and their } \\
\text { impact on advances in } \\
\text { biomedical science. }\end{array}$ \\
\hline \multirow[t]{2}{*}{ Bioscience } & $\begin{array}{l}\text { Methods of acquiring, interpreting } \\
\text { and analysing biological } \\
\text { information with a critical } \\
\text { understanding of the appropriate } \\
\text { contexts for their use through the } \\
\text { study of texts, original papers, } \\
\text { reports and data sets. }\end{array}$ & $\begin{array}{l}\text { Be able to plan, execute } \\
\text { and present an independent } \\
\text { piece of work (eg a project), } \\
\text { in which qualities such as } \\
\text { time management, problem } \\
\text { solving and independence } \\
\text { are evident, as well } \\
\text { interpretation and critical } \\
\text { awareness of the quality of } \\
\text { evidence. }\end{array}$ & $\begin{array}{l}\text { Be able to construct } \\
\text { reasoned arguments to } \\
\text { support their position on } \\
\text { the ethical and social } \\
\text { impact of advances in } \\
\text { the biosciences. }\end{array}$ \\
\hline & & $\begin{array}{l}\text { Have ability in a range } \\
\text { of practical bioscience } \\
\text { techniques, including... } \\
\text { testing of hypotheses. }\end{array}$ & \\
\hline \multirow[t]{2}{*}{ Earth Science } & $\begin{array}{l}\text { Analysing, synthesising and } \\
\text { summarising information critically, } \\
\text { including prior research. }\end{array}$ & $\begin{array}{l}\text { Present an independent } \\
\text { project with limited reliance } \\
\text { on guidance. }\end{array}$ & $\begin{array}{l}\text { Recognition of the } \\
\text { moral and ethical } \\
\text { dimensions of issues }\end{array}$ \\
\hline & & $\begin{array}{l}\text { Collecting and integrating } \\
\text { several lines of evidence } \\
\text { to formulate and test } \\
\text { hypotheses. }\end{array}$ & $\begin{array}{l}\text { and investigations and } \\
\text { the need for professional } \\
\text { codes of conduct. }\end{array}$ \\
\hline Health Studies & $\begin{array}{l}\text { Locate, review, evaluate, carry out, } \\
\text { report and analyse research in } \\
\text { health studies. }\end{array}$ & $\begin{array}{l}\text { Apply an appropriate critical } \\
\text { framework to use and } \\
\text { evaluate research in health } \\
\text { studies. }\end{array}$ & $\begin{array}{l}\text { Health studies should } \\
\text { be informed by other } \\
\text { academic disciplines... } \\
\text { (including) ethics. }\end{array}$ \\
\hline
\end{tabular}

\footnotetext{
${ }^{1}$ Benchmark statements for Bioscience and other related disciplines (Anthropology, Biomedical Science, Earth Science, Health Studies ) selected from the 57 honours degree subject benchmarks available (www.QAA.ac.uk). The benchmark statements were analysed to identify the range of requirements for hypotheses-driven research, the skills in research and ethics which a typical graduate should attain.
} 
between them and the research community (Otlowski, 2007; Silverman and Lemaire 2006; Kettis-Lindblad et al 2006). It is important therefore that universities adopt policies to ensure that research performed under their auspices maintains this public confidence. In 2003, Tinker and Coomber (2004) carried out a survey to determine the extent to which UK universities undertake ethical scrutiny of research. They received responses from 78 of the universities polled $(68 \%), 43$ of which indicated that they reviewed student research projects. They noted that over half of the respondents had set up their committees since 2000 and observed many different systems for review of research, including review by one person, (supervisor, Dean of Faculty, Research Director), by two other academics from the school, by the school committee and by central committee. Almost a decade after this review was undertaken, it is important to consider whether the ethical review of student projects has become more widely adopted, and whether it is possible to identify best practice for the proportionate, consistent and efficient ethical review of student projects.

\section{The risks and benefits of student projects}

The subject benchmark statement for the Biosciences published by the Quality Assurance Agency (QAA) defines the broad expectations of skills and knowledge a typical graduate would be expected to develop during the course of their study in a given subject area. Benchmark statements for the Biosciences, plus four other disciplines (Anthropology, Biomedical Science, Earth Science and Health Studies) were analysed to identify the range of requirements for hypotheses-driven research, the skills in research which a typical graduate should attain, and what research skills inform the subject area. The benchmark statements were also reviewed to determine what ethical knowledge graduates would be expected to develop during the course of their study (Table 1).

It can be seen from Table 1 that the main goal of an honours degree is the development of research skills relevant to the subject area. Thus undergraduate student projects would be expected to use a systematic and transparent methodology appropriate to their subject area. It is recognised that student projects can encompass a range of activities, in addition to studies which require the participation of human subjects; projects may use non-human animals, impact on the environment, use sensitive data, or may raise issues that are of concern to society. These activities may raise important ethical concerns of consent, privacy, autonomy, justice and well-being (Table 2).

Table 2 Research which may raise ethical concerns

\begin{tabular}{|c|c|}
\hline Research which: & Ethical issues \\
\hline Uses human subjects & $\begin{array}{l}\text { consent, confidentiality, autonomy, non- } \\
\text { malfeasance, beneficence, justice, }\end{array}$ \\
\hline Uses non-human animals & non-malfeasance, beneficence, \\
\hline May have a significant impact on the environment & non-malfeasance, beneficence, \\
\hline $\begin{array}{l}\text { Uses sensitive data, from groups (e.g. } \\
\text { communities, societies), companies or individuals }\end{array}$ & $\begin{array}{l}\text { consent, confidentiality, autonomy, non- } \\
\text { malfeasance, beneficence, justice. }\end{array}$ \\
\hline $\begin{array}{l}\text { Produce outcomes that may raise societal } \\
\text { concerns }\end{array}$ & justice, non-malfeasance, beneficence \\
\hline
\end{tabular}

The perceived wisdom that student projects are small scale, non-invasive projects and therefore have minimal risks is rejected by Edwards (2009). Edwards identified two specific risks in student projects: the researcher is inexperienced and the conflict of interests between the researcher, whose primary goal is to get an educational qualification, and the research participant. Other risks and benefits that may be more frequently observed in student led projects than those led by a more experienced researcher are outlined in Table 3. 
Table 3 Potential risks and benefits of student research

\begin{tabular}{|c|c|c|}
\hline Issue & Potential Risks & Potential Benefits \\
\hline Researcher & Inexperienced & Less invasive studies. \\
\hline \multirow{3}{*}{ Smaller cohorts } & & Gains important research skills \\
\hline & $\begin{array}{l}\text { Less likely to generate statistically } \\
\text { significant results }\end{array}$ & \multirow[t]{2}{*}{$\begin{array}{l}\text { Less potential for harm due to smaller } \\
\text { numbers involved. }\end{array}$} \\
\hline & $\begin{array}{l}\text { Less likely to produce generalizable } \\
\text { results }\end{array}$ & \\
\hline \multirow{3}{*}{$\begin{array}{l}\text { Recruitment from } \\
\text { university staff and } \\
\text { students. }\end{array}$} & Coercion & \multirow{3}{*}{$\begin{array}{l}\text { Participants have good understanding } \\
\text { of research: terms, protocols, } \\
\text { their rights. Access to Research } \\
\text { Governance advice. }\end{array}$} \\
\hline & Over-tested population & \\
\hline & $\begin{array}{l}\text { Data not generalizable (e.g. limited } \\
\text { age profiles, education status) }\end{array}$ & \\
\hline $\begin{array}{l}\text { Research } \\
\text { undertaken in } \\
\text { university }\end{array}$ & $\begin{array}{l}\text { May not have established links with } \\
\text { local support services, e.g. health and } \\
\text { social services }\end{array}$ & $\begin{array}{l}\text { Risks to researcher can be managed } \\
\text { (safe working environment) }\end{array}$ \\
\hline \multirow[t]{2}{*}{ Short-time scale } & Study not completed & \\
\hline & Results of study not disseminated & \\
\hline
\end{tabular}

The primary aim of undergraduate student projects is to develop research skills; as endorsed by the graduate standards established by the Quality Assurance Agency (QAA). Thus the value of the information generated by the project may make a minor contribution to a riskbenefit analysis; however the research may still be regarded as beneficial if students are given the opportunity to develop relevant research skills, including skills in ethical analysis. This is a tangible benefit of the project, and the review should take into consideration the types of skills being developed. Review by university committees should ensure that the applicant receives advice on how the research design may be modified to resolve ethical issues without compromising the scientific validity of the study; allowing the student to develop a deeper understanding of the ethical issues and ethical research design.

From the subject benchmarks analysed in Table 1, only Anthropology requires that students can 'demonstrate an ability to assess and analyse the ethical implications of anthropological research and enquiry', whilst the Bioscience and Biomedicine statements both identify a need to understand the ethical issues raised by advances in the life sciences. Ethical review will provide students with practical experience in considering ethical issues raised by their study and how to design an ethical research project that minimises risks to participants whilst maximising benefits to society. This requires that the project employs acceptable scientific methods and has the potential to produce reliable and valid data. These skills are an integral part of the research process. The requirement for a project to be submitted to ethical review will ensure that the student gives careful consideration to these issues, and gain valuable practical experience of identifying ethical issues, and minimizing risks.

Research is far more strictly regulated than other activities, which may be more intrusive (e.g. journalistic interviews, publication on social network sites), humiliating (e.g. participation in reality television shows) or harmful (e.g. extreme sports). Ethical review of student projects can be a time consuming and resource intensive exercise. It is important to recognise that ethical review of student projects produces many benefits for the student, the university and the general public. The key is to ensure that review is consistent, proportionate and efficient. 


\section{Review of current system}

One unavoidable issue with student research is the time constraints; the majority of undergraduate research is undertaken in the final year of study, and it is necessary that students have the required ethical approval in place prior to any data collection. Delays in receiving approval can therefore have severe consequences for the student. Gelling (2010) reported that less sub-doctoral research is taking place, due to the requirement for ethical approval, and other anecdotal evidence has indicated that many project supervisors avoid projects requiring ethical approval, even those that may be considered of low risk. If this is the case then the ethical approval system is failing researchers, students and society.

Table 4 Analysis of the processes in place for the ethical review of student research projects in UK Universities

\begin{tabular}{|c|c|c|c|c|}
\hline Minimal Review & $\square$ & 2 & Rigorou & s Review \\
\hline $\begin{array}{l}\text { Project } \\
\text { Classification }\end{array}$ & Applicant & Supervisor & $\begin{array}{l}\text { REC member / } \\
\text { officer }\end{array}$ & Committee \\
\hline $\begin{array}{l}\text { Review of Low } \\
\text { Risk Projects }\end{array}$ & Supervisor & Expedited review & Committee & $\begin{array}{l}\text { Independent } \\
\text { committee }\end{array}$ \\
\hline $\begin{array}{l}\text { Review of High } \\
\text { Risk Projects }\end{array}$ & $\begin{array}{l}2 \text { reviewers ( } 1 \\
\text { may be project } \\
\text { supervisor) }\end{array}$ & Expedited review & Committee & $\begin{array}{l}\text { Independent } \\
\text { committee }\end{array}$ \\
\hline $\begin{array}{l}\text { Constitution of } \\
\text { Committee }\end{array}$ & $\begin{array}{l}\text { Membership from } \\
\text { school/ research } \\
\text { group }\end{array}$ & $\begin{array}{l}\text { Inclusion of lay } \\
\text { and/or external } \\
\text { members }\end{array}$ & Virtual Committee $^{\dagger}$ & $\begin{array}{l}\text { Independent } \\
\text { committee }\end{array}$ \\
\hline
\end{tabular}

'Some virtual committees had a wider membership, but others were constituted from the school or research group.

The close relationships between medical schools and the NHS has meant that medical student projects often requires review by an NHS REC, however student research in the Biosciences may raise ethical concerns but are not subject to this system. For research undertaken within UK universities that does not fall under the remit of external review bodies such as NRES; there is no set process for ethical review and each university has established their own review processes (Anderson-Ford, 2007). A significant criticism levelled at the Local Research Ethics Committees (LRECs) which were established to review NHS research in the 1970s, were that they lacked consistency and independence (Lock 1990; Warnock 1988); similar claims could now be made of university ethics review processes. Table 4 provides an illustrative example of the range of ethical approval processes in place at UK universities. Table 4 was generated through an Advanced Google Search of ethical review within the domain 'ac.uk', the first 100 results included over 30 separate institutions, these were analysed according to four criteria until data saturation was reached.

- Procedures for classification of projects as high or low risk

- Reviewers (number and independence)

- Constitution of the committee

- Processes for audit

The research assessment rank for Biological Science was determined for each of the 30 institutions (The Complete University Guide, 2012). Two thirds of the selected institutions were ranked in the top 30 for research in the biological sciences, indicating a slight bias in the selection process towards higher profile researcher institutions. 
Most institutions identified a separate review process for student research (undergraduate and postgraduate taught) which was distinct from research conducted by academic staff or postgraduate research students. The procedures for classification of projects as high risk and low risk varied slightly between the institutions, however the main criterion for classifying a project as low risk were:

- Uses tissue or data that are anonymous to the researchers;

- Participants able to give autonomous informed consent (no issues due to lack of capacity or coercion);

- Research does not pose any more risks than research participants would expect to experience in normal routines;

- Questionnaires or focus group which does not raise any sensitive issues or where accidental disclosure would not have serious consequences.

Expedited review was offered in all but one of the observed institutions for evaluation of low risk projects; and carried out either by: the project supervisor; one independent member of the appropriate committee; or by the project supervisor in conjunction with a member of the committee. Many institutions used a check list system, whereby the applicant or his supervisor could identify the project as low risk. However, what constitutes an acceptable risk or a sensitive issue, is subjective, and it was not always clear whether these classifications were subject to audit or review, or whether the student or the supervisor had been adequately trained in how to assess the risks. Only two of the institutions investigated, addressed the issue of independence of the review committee, whilst one identified a formal audit process. There was no clear link between research assessment rank and the rigor of review process, for example whilst two institutions in the top ten had the most rigorous process, one institution in the top 10 had the least rigorous processes. This analysis was not intended as an exhaustive review of the review processes, but an indication of the range of processes that were being carried out in UK universities. Clearly, other institutions may have additional processes in place which were not apparent from a review of their website material.

Several innovative approaches were notable including the approval of generic projects, the approval of standard research protocols and virtual committees. The approval of standard protocols allowed high risk projects to receive expedited review as long as they adhered to the authorised protocols. The use of virtual committees where applications and reviews were distributed electronically appeared to provide an efficient review process and facilitated the inclusion of lay members and/or members external to the school or research group. The use of technology to facilitate real-time discussion can provide virtual committees with an efficient mechanism for explicit discussion of the ethical issues raised by a study.

Ethical review of student projects should follow a rigorous and independent process. Clearly in those instances where the project supervisor is responsible for classifying a project as either high or low risk and reviewing the low risk project, there are issues of independence and oversight. However review should not be overly bureaucratic, nor cause exceptional delays to student projects, and universities need to ensure that reviewers have received adequate training.

Several alternatives to ethical review by committee have been proposed. For children's science fair projects, Tolich (2008) suggested that teaching staff generate a pre-approved list of topics with minimal risks. Whilst this approach was aimed at protecting child researchers, it could be modified for student projects, and is similar to the approval of block projects, or approved protocols described above. Expedited review of low risk projects followed by independent audit, also offers a practical approach for transparent and proportionate review. 


\section{Suggested Procedures for Facilitating Ethical Approval of student projects}

A number of tools can be provided, to facilitate students receiving ethical approval for their project. These include:

- Check lists for projects that meet criteria as 'low risk'

- Prior approval of generic projects

- Prior approval of standard protocols

- Use of standard/ customizable consent forms

- Use of templates for participant information sheets

- Approved recruitment methods

Projects can then go forward for review as:

\section{Low Risk Projects}

- Confirmation of low risk status

- Expedited review by independent reviewer

\section{High Risk Projects (I)}

Projects which use previously approved protocols and proscribed recruitment and consent protocols should still be eligible for expedited review. As these projects represent a higher risk, the review should be undertaken by at least two independent reviewers (not involved directly in the research), one of whom should be from outside the research group/ school.

\section{High Risk Projects (II)}

Review by full committee is only required where the criteria for Low Risk or High Risk Projects (I) are not met.

\section{Central or Devolved Committee Structure}

Two basic models for University Research Ethics Committees (UREC) have emerged over the last decade; see Tinker and Coomber (2004) and Hunter (2008). The central model, whereby a single central UREC is responsible for scrutiny of all projects, and a devolved structure where a school, faculty or research group based REC scrutinizes all applications, with only a few high risk projects being submitted to the higher UREC. It is estimated that a typical university should expect to initiate 1000 projects per year that require ethical review (Hunter, 2008); this is clearly too onerous a work load for a single UREC. However the devolved model may present issues of conflict of interest, lack of ethical expertise, and inconsistency. Hunter (2008) proposed the use of a rotating committee model, where a number of central committees are established, with membership from across the university. With each committee meeting on a regular basis, this model could provide reduced waiting times for review and have a balanced membership which includes trained ethicists, a diverse range of subject specialists, and lay persons.

\section{Audit}

By supporting these review methods with audit, and publication of lay summaries the university sector can move to a more efficient and transparent process for the proportionate review of student research.

\section{Conclusions}

A wide range of ethical review processes are currently in operation across the university sector. These processes vary in terms of efficiency (the resources required and the turnaround times) 
and exhibit many of the flaws that prevailed in ethical review of NHS research in the 1970s (Warnock, 1988), such as lack of independence, transparency, and training of committee members. To retain the confidence of staff, students and the wider community universities should consider whether their processes are fit for purpose and offer a proportionate and efficient review of student projects.

Corresponding Author: Catherine J Hack, University of Ulster, Cromore Road, Coleraine, Co.Londonderry. BT521SA. Email: Cj.hack@ulster.ac.uk Tel: 02870324728

\section{References}

Anderson-Ford, D. (2007) UK Universities Research Ethics Committee working group joins AREC, Research Ethics Review, 3,(1), 30-32

Edwards, S. (2009) Student projects in medicine: A lesson in science and ethics. Accountability in Research, 16, 285-306

Gelling, L. (2010) Student Research, Nurse Researcher, 17, (3), 3

Hazelgrove, J. (2002) The Old Faith and the New Science: The Nuremberg Code and human experimentation ethics in Britain 1946-73. The Society for the Social History of Medicine 15(1): 109-135 doi:10.1093/shm/15.1.109

Hunter, D. (2008) The ESRC research ethics framework and research ethics review at UK universities: rebuilding the tower of Babel REC by REC. J Medical Ethics, 34, 815-820

Kettis-Lindblad, A., Ring, L., Viberth, E, Hansson, M.G. (2006) Genetic research and donation of tissue samples to biobanks. What do potential sample donors in the Swedish general public think? European Journal of Public Health. 16(4),433-40

Lock, S. (1990) Monitoring research ethical committees, British Medical Journal, 300, 61-62

Otlowski, M. (2007) Donor Perspectives on Issues Associated with Donation of Genetic Samples and Information: An Australian Viewpoint. Journal of Bioethical Inquiry 4 (2), 135-150 DOI10.1007/s11673-007-9055-4

Silverman H.J. and Lemaire F. (2006) Ethics and research in critical care, 32 (11),1697-705

Tinker, A. and Coomber, V. (2004) University Research Ethics Committees Their role remit and conduct, London. Kings College London and the Nuffield Foundation http://www.kcl. ac.uk/content/1/c6/02/96/45/UniversityResearchEthicsCommittee.pdf, accessed October, 2011

Tolich, M. (2008) Guidelines for Community-based Ethics Review of Children's Science Fair Projects Journal of Bioethical Inquiry 5, (4), 303-310

Warnock, M. (1988) A national ethics committee, British Medical Journal, 297, 1626-7

\section{Websites}

Subject Benchmarks, Quality Assurance Agency (QAA) http://www.qaa.ac.uk/ academicinfrastructure/benchmark/default.asp (accessed 7th May, 2011)

The Complete University Guide (CUG) http://www.thecompleteuniversityguide.co.uk/ (accessed 6 ${ }^{\text {th }}$ April, 2012) 